\title{
The Art of Adaptation and Self-Promotion: Carlo Gozzi's La Principessa filosofa
}

Carlo Gozzi's teatro spagnolesco can serve as a particularly enlightening example for a reflection on, and re-evaluation of, the wide-ranging influences of early modern Spanish theatrical practices on the geographical and cultural spaces conquered by this empire. The eighteenth-century Venetian playwright (1720-1806), also referred to as the Italian Shakespeare due to the irregular and extravagant character of his dramatic production, ${ }^{1}$ adapted about twenty comedies from the Spanish drama of the Siglo de Oro for the Italian stage. Better known for his avantgarde theatrical fables, from 1767 Gozzi found not only a new source of inspiration in Spanish comedies, but also, as he saw it, a way to renew and revitalise Italian theatrical practice more generally. ${ }^{2}$ The playwright himself considered this part of his dramatic production to be no less important than his highly successful Fiabe teatrali (written and performed in 1761-1765) and even claimed in the preface to one of his Spanish comedies that "[...] se si vorrà scrivere una storia veridica de' nostri Teatri, [...] si dovrà fare [...] menzione [...] del mio nuovo genere tratto dagli argomenti Spagnuoli" [whoever decides to write the true history of our theatres should mention [my] new genre based on Spanish scenarios]. ${ }^{3}$

Whereas Gozzi's Spanish plays have so far remained largely unknown to the general public, there has been a revival of research interest in his adaptations of Spanish drama, thanks to the recent discovery of an extraordinary family archive containing 9500 unpublished folios and manuscripts that shed new light on the composition process of the playwright's theatrical and theoretical writings. ${ }^{4}$ The

1 Giuseppe Baretti, An Account of the Manners and Customs of Italy: With Observations on the Mistakes of Some Travellers, with Regard to that Country [1768], in: Baretti, Opere, ed. Franco Fido (Milano: Rizzoli, 1967), pp. 611-646, p. 628.

2 Carlo Gozzi, La più lunga lettera di risposta che sia stata scritta inviata da Carlo Gozzi a un poeta teatrale italiano de' nostri giorni, in: Opere edite ed inedite del Co: Carlo Gozzi, 14 vols. (Venezia: Zanardi, 1801-1804), vol. 14, pp. 3-168, p. 54.

3 Gozzi, Preface to I due fratelli nimici, in: Opere del Co: Carlo Gozzi, 8 vols. (Venezia: Colombani, 1772-1774), vol. 5, pp. 283-287, pp. 286-287.

4 Gozzi's adaptations from Spanish comedies suffer from the fact that only a small percentage of these plays are available in modern, scholarly editions (I due fratelli nimici, in: Opere: Teatro e polemiche teatrali, ed. Giuseppe Petronio [Milano: Rizzoli, 1962] and Le droghe d'amore, ed. Camilla Guaita [Milano: Cuem, 2006]), and none of them is regularly performed in theatres. After the discovery of the playwright's archive in 2004 and its subsequent acquisition by the Biblioteca Nazionale Marciana in Venice Gozzi's teatro ispano-veneto has begun to attract the scholarly 
theoretical conceptualisation of the metaphor of culture as a net enabling the multi-directional circulation of material forms and cultural artefacts (a metaphor whose productivity and explanatory potential are elucidated by the essays in this volume) can provide further insights into Gozzi's adaptations and, in a broader sense, into the complex relationships between Italian and Spanish dramatic practices. This new approach to the study of drama allows to show how Spanish materials were diffused and made available in mid-eighteenth-century Venice and to highlight the process of transculturalisation. Drawing on the concept of culture as a dynamic net, as outlined by Joachim Küpper, ${ }^{5}$ I will address the question of what is transferred with the dramatic text and what is altered in the process of adaptation. Moreover, a case study of one of Gozzi's Spanish comedies, La Principessa filosofa, o sia Il controveleno [The Princess Philosopher, or the Antidote] (1772), and its source text, Desdén con el desdén [Disdain Meets With Disdain] (1654) by Agustín Moreto y Cabaña (1618-1669), will raise a further question in my investigation, namely: did the conceptualisation of intellectual property develop differently in the field of dramatic literature compared to non-dramatic forms? In drawing my conclusions, I will argue that the entangled history of the performance of Gozzi's play is particularly illuminating in endeavouring to understand the impact of authorial agency on the circulation of cultural artefacts.

\section{Gozzi and the Cultural Net}

Let me start with some preliminary considerations on why Gozzi's adaptations from Spanish drama of the Siglo de Oro lend themselves to being examined in terms of the circulation of theatrical material within the cultural net. First of all, Spain was the dominant power in Italy in the early modern period and played a significant role in its history during the Seicento. Cultural and political encounters between Italy and Spain were the order of the day, with numerous exchanges of authors, playwrights and theatre troupes. Even when Spanish rule in Italy gave way to Austrian domination in 1715, the interchanges between the two countries continued well into the eighteenth century. Gozzi's own encounter with Spanish

attention it merits. See especially the collections of essays dedicated to these plays by Susanne Winter, ed., Carlo Gozzi: I drammi 'spagnoleschi' [Heidelberg: Winter, 2008] and Javier Gutiérrez Carou, ed., Metamorfosi drammaturgiche settecentesche: Il teatro 'spagnolesco' di Carlo Gozzi [Venezia: lineadacqua, 2011]).

5 For the conceptual framework of the DramaNet project approach, see the chapter by Joachim Küpper in this volume. 
culture was enabled by general factors, such as the diffusion of travel writings by Italian tourists visiting Spain $^{6}$ and the settlement of Jesuits in Italy, ${ }^{7}$ as well as more personal circumstances, such as his friendship with the major Venetian scholar of Spanish literature, Giovanni Battista Conti, ${ }^{8}$ and the playwright's collaboration with Antonio Sacchi's itinerant troupe, which at the beginning of their relationship had just returned from Portugal.

Along with these exchange processes, which brought about Gozzi's encounter with Spanish drama, the lively intra-European circulation of texts and performances should also be taken into consideration. Indeed, although Gozzi's Principessa filosofa remains faithful to the Spanish original, its title shifts attention onto the single character, away from Moreto's emphasis on the action, revealing similarities with both Molière's 1664 comédie-ballet, La princesse d'Elide, and Pietro Chiari's comedy, Alcimena principessa delle isole Fortunate (1750). Another possible source for Gozzi's play is Luigi Riccoboni's Rebut pour Rebut (1717), first staged in Paris by the troupe of the Nouveau Thêâtre Italien. Moreover, Gozzi may have also been familiar with the Italian sixteenth-century adaptations of Moreto's play by Antonio Parrino (Amare e fingere, 1675) and Arcangelo Spagna (Lo sdegno con lo sdegno si vince, 1709). ${ }^{9}$ The Italian reception of Spanish theatre in the eighteenth century can be therefore defined in terms of a dynamic contextual network, in which the relationships between texts were often mediated by both French dramatic culture and the native Italian tradition. Considering the Venetian theatrical

6 Particularly relevant in this regard are Giuseppe Baretti's Lettere familiari a' suoi tre Fratelli, Filippo, Giovanni, e Amedeo from Portugal and Spain (1762-1763) and A Journey from London to Genoa: through England, Portugal, Spain, and France (1770). Baretti was Gozzi's friend and admirer, and after he made his way back from England to Italy via the Iberian Peninsula, he most likely gave the playwright an enthusiastic account of Spanish drama (Piermario Vescovo, "AAlcune reliquie de' teatrali spettacoli spagnuoli': Da uno 'spagnolismo' a un altro,” in: Winter, ed., Carlo Gozzi, pp. 57-71). Indeed, he considered Lope de Vega and Calderón among the greatest of poetic geniuses, describing their works as original, forceful and elegant (Baretti, Opere, pp. 647 f.; Robert Bufalini, "The Lapidation of Giuseppe Baretti and the Invective of His Lettere familiari from Portugal and Spain,” Modern Language Notes 125.1 (2010), pp. 141-152, p. 151).

7 One of these Jesuits, Cristoforo Tentori, was the tutor to Almorò Tiepolo's family, to which Gozzi's mother belonged. See Franco Fido, La serietà del gioco: Svaghi letterari e teatrali nel Settecento [Pisa: Pacini Fazzi, 1998], chap. 4.2 “I drammi spagnoleschi,” pp. 130-158, p. 134.

8 Enrico Carrara, Studio sul teatro ispano-veneto di Carlo Gozzi (Cagliari: Valdes, 1901), p. 9; Vittorio Cian, Italia e Spagna nel secolo XVIII: Studi e ricerche (Torino: S. Lattes, 1896), pp. 42-46; Fido, La serietà del gioco, p. 134.

9 On Gozzi’s sources for La Principessa filosofa, see Monica Pavesio, “Rebut pour Rebut-Ritrosia per ritrosia: un canovaccio del Nouveau Théâtre Italien di Luigi Riccoboni come possibile fonte de La principessa filosofa di Gozzi,” in: Winter, ed., Carlo Gozzi, pp. 193-206; Maria Grazia Profeti, “Gozzi e l'informe e stravagante teatro spagnolo'," in: Winter, ed., Carlo Gozzi, pp. 23-41, p. 31. 
milieu's extreme receptiveness to cultural material of any kind, the adaptations from Spanish Golden-Age drama provided Gozzi with a means to link his plays to a wider network of literary, ideological and social texts.

\section{"Una idea da me rovesciata e riedificata a mio modo"}

The metaphor of the cultural net is thus particularly useful in describing the interconnected networks of production and consumption in which the theatrical texts were enmeshed. Given that the adaptation of drama involves not only a translation from one language to another but also from one theatrical practice to another, it is vital to address the question of what changes were made in the process of adapting the play for the genio italiano [the Italian genius] and the gusto natio [national taste].

Moreto's Desdén con el desdén is a typical love comedy in which three noblemen vie for the attention of the princess of Barcelona. Diana, the lady in question, is disdainful and intellectually opposed to love and marriage. However, one of her suitors, Carlos, succeeds-with the help of his servant, the gracioso Polilla-in winning her affection. His strategy consists in repaying Diana's disdain with his own apparent disinterest, and, indeed, the princess swallows the bait. Wounded by Carlos's seeming aloofness, Diana hence resolves to have him fall in love with her. She is thus led into the trap devised by Carlos, and when he takes the decisive step of his plan by feigning interest in her lady-in-waiting, Diana is irretrievably lost.

These tangled situations of the Spanish play appealed to Gozzi, who considered theatre the "recinto di divertimento" [enclosure of diversion]. ${ }^{10}$ He borrowed Moreto's entire plotline of a princess who rejects marriage and thus threatens the social order, as well as the principal motifs of love and feigned disdain. However, although Gozzi was willing to acknowledge his debts to Moreto, he also insisted, in the preface to his adaptation, on the radical difference between his comedy and those of his predecessors:

El Desden con el desden: Commedia di D. Agostino Moreto, m'ha dato l'argomento per questo Dramma. Moliere ha rubata l'idea della sua Principessa d'Elide al Moreto, ma egli ha

10 For Gozzi's definition of theatre as "recinto di divertimento" or "recinto di passatempo," see the prefaces to Il Fajel ("Prefazione del Traduttore," in: Il Fajel: Tragedia del Sig. D’Arnaud tradotta in versi sciolti dal Co: Carlo Gozzi [Venezia: Colombani, 1772], pp. 5-36, esp. p. 32) and I due fratelli nimici (p. 284).

Note: The heading of this section is taken from Gozzi, La più lunga lettera di risposta, p. 36. 
fatto un'opera che punto non ha che fare colla mia Principessa filosofa. Il confronto è facile. Si troverà, che'l mio Dramma è differentissimo e nell'ossatura, e ne' dialoghi dal Desden con el desden del Moreto, e dalla Principessa d'Elide del Moliere [....]. ${ }^{11}$

[El Desdén con el desdén, a comedy by D. Agostino Moreto provided me with an argument for this drama. Molière stole the idea for his Principessa d'Elide from Moreto and wrote a work that has nothing to do with my Principessa filosofa. The comparison is easy: my play is very different both in structure and in its dialogues from both Moreto's Desdén con el desdén and Molière's Principessa d'Elide (...).]

In his Memorie inutili [The Useless Memoirs] (1797), Gozzi distances himself again from his sources, claiming that he "trass[e] dal fondo delle Commedie spagnole molti Drammi, [...] enunziando sempre que' Drammi come tratti, e non come tradotti” [I drew on many Spanish comedies, always specifying that my works were inspired by them and not translated from them $].{ }^{12}$ On numerous other occasions, Gozzi challenges his critics and invites them to look for the differences between his plays and their originals. ${ }^{13}$ Let us follow the playwright's lead and explore what makes Gozzi's adaptation so different-differentissimo-from the source texts, where the playwright even claims that if someone tried to revive and stage Molière's translation of Moreto's comedy, it would not enjoy the same success as his own play (p. 149). Since both Moreto's and Gozzi's plays are essentially comedies of character, and it is indeed the dramatis personae who engage the audience's imagination and are responsible for the plays' aesthetic effects, I will focus on how the relationships between the principal characters-the princess Teodora, her suitor Don Cesare (the counterparts of Moreto's Diana and Carlos) and their intermediary, Giannetto (the equivalent of the gracioso Polilla)-are treated in the Italian adaptation.

11 All quotations from Gozzi’s play are taken from the editio princeps: Gozzi, La Principessa filosofa, o sia Il controveleno, in: Opere del Co: Carlo Gozzi, vol. 5, pp. 145-280 (here "Prefazione,” pp. 147-148). Hereafter, page numbers will be cited parenthetically. All translations are my own.

12 Gozzi, Memorie inutili, edd. Paolo Bosisio and Valentina Garavaglia, 2 vols. (Milano: LED, 2006), vol. 2, part 3, "Lettera confutatoria da me scritta l'anno 1780, e indirizzata a Pietro Antonio Gratarol a Stockholm,” p. 825. Hereafter, followed by chapter, page, and then volume number in arabic numerals. Unless otherwise noted, all translations are mine.

13 See, for example, the preface to Il pubblico secreto, in: Opere edite ed inedite, vol. 6, p. 5: "[s] commetto, che l'opera mia è differente molto da quella di Calderone, e da quella del Cicognini" [I bet my work is very different from that of both Calderón and Cicognini]. 


\title{
Poetics of Adaptation
}

Moreto's Carlos is a courtly character conscious of his social importance and duties. He also possesses a profound knowledge of human behaviour and the mechanisms of desire. Indeed, Carlos falls in love with Diana despite her merely ordinary beauty ("una hermosura modesta"14), because for the first time in his life he is unable to get what he wants. He explains that "Que aunque sea la codicia / de más precio lo que alcanza / que lo que se le retira, / sólo por la privación / de más valor lo imagina" [Because even though we may desire what we can obtain more than what is withheld from us, only because we are deprived of the latter, we imagine it to be of greater value]. ${ }^{15}$ Realising that only the challenge which the unattainability of the desired object represents for his own ego will shake the princess's indifference, Carlos decides to feign disinterest in Diana's charms.

Gozzi's Don Cesare appears to be the complete opposite of his Spanish forebear. As he confides to Giannetto, he is hopelessly in love with the princess of Barcelona and completely overwhelmed by the force of his feelings:

\author{
Don Cesare: Tento con te uno sfogo \\ D'un'affanno angoscioso, e che m'uccide \\ Omai chiuso nel seno. Io sono, amico, \\ Straziato il core, oppresso dall'angoscia \\ Sol per colei, che prima nominasti. \\ (s'appoggia ad una spalla di Giannetto piangendo) \\ (p. 154) \\ [DoN CESARE: In you I seek the release \\ For the painful grief that is killing me, \\ Now locked in my bosom. My heart, my friend, \\ Is tortured and burdened with anguish \\ Only for her, whom you mentioned earlier. \\ (crying, he leans on Giannetto's shoulder)]
}

Don Cesare also lacks the intelligence and spirit of initiative of his Spanish counterpart, and the unpromising beginning of the courtship of Donna Teodora leaves him in a state of profound melancholy, as revealed by the very first stage direction in the opening scene of the first act: "D. Cesare starà sedendo innanzi, appoggiato con un gombito ad un tavolino, con una guancia alla mano, immerso in

14 Agustín Moreto, El desdén, con el desdén, ed. Enrico di Pastena, Biblioteca clásica (Barcelona: Crítica, 1999), v. 84. Quotations from the play are followed by line numbers, referring to this edition. Unless otherwise noted, all translations are mine.

15 Vv. 264-268. Translation is from Raymond R. MacCurdy, ed., Spanish Drama of the Golden Age: Twelve Plays [New York, NY: Appleton-Century-Crofts, 1971], p. 585. 
una profonda malinconì” [D. Cesare is sitting leaning forward, his elbow on a small table and his hand on his cheek, in a state of profound melancholy] (p. 151). Giannetto, the go-between between Don Cesare and the object of his affections, therefore has to devise a plan whereby the unfortunate lover can get the better of the princess. Thus, whereas Moreto preserves the dignity of Carlos' character, Gozzi transfers the intellectual qualities of the noble protagonist to the low figure of the Venetian servant.

Giannetto, like his Spanish counterpart, the gracioso Pollila, is thus constantly at the centre of the dramatic action, performing a dual function: on the one hand, he is the playwright and the stage director who controls the role-playing of the other characters and, on the other, he is the spectator-commentator of their actions. As playwrights, Giannetto and Polilla are responsible for bringing the destined couples together, whereas the role of providing commentary on the dramatic action enables them to communicate with the audience more than other characters. However, if Polilla's metaphorical language creates a linguistic substructure underlying the surface plot, Giannetto's function is to entertain, using his Venetian dialect and his Pantalone-like manners to engage a theatre-going public seeking only entertainment and laughter ("Volli da questo Dramma lontane le nostre maschere, sostituendo però il carattere d'un Veneziano faceto per ridur l'opera più intesa dall'universale, è più popolare"; [I wanted to keep the commedia dell'arte stock characters away from this play, and I thus substituted for them the figure of the funny Venetian fellow in order to make the work more universally understandable and more popular]). ${ }^{16}$

Both Moreto's Diana and Gozzi's Teodora reject courtship and concomitantly marriage. They thus fall outside the norm, because by refusing to fulfil their social duty of guaranteeing political succession in their kingdoms, the heroines try to impose a pattern of conduct alien to a person of their rank. Diana is not really a comic character, however, since the question she is raising is a serious one, namely, whether a woman is free to choose her course in life without interference from tradition and social conventions. ${ }^{17}$ Compared to her Spanish counterpart, Gozzi’s Teodora is a much less complex character, since her position regarding marital relationships recalls more that of Turandot, the ultra-feminist from Gozzi's homonymous fairy-tale play, the exotic princess who exudes hostility and disdain for the male sex.

16 Gozzi, Preface to La Principessa filosofa, p. 148.

17 Bruce W. Wardropper, “Moreto’s El Desdén con el Desdén: The ‘Comedia’ Secularized,” Bulletin of Hispanic Studies 34 (1957), pp. 1-9, p. 3. 
Like Carlos, Diana never allows passion to get the better of her: even when she admits that her love for her suitor has been aroused by jealousy of her cousin Cintia, she is still able to reason effectively. Her Italian counterpart also considers herself aloof and self-controlled, but in the scène probante (Act 2 scene 2), where Gozzi measures the positions of his protagonists and prepares them for yet another meeting, which further modifies their personalities, the stage directions reveal that Donna Teodora is no more than an irritable and short-tempered woman: “invasata alquanto” [rather possessed] (p. 186), "riscaldata” [heated] (p. 187), "smaniosa per [...] so noncuranza” [stung by his disinterest] (p. 189), "fiera," "collerica” [imperious, choleric] (p. 196), “sorpresa, e un poco riscaldata” [surprised and a little bit warmed up], "più riscaldata” [more warmed up], "un poco attonita” [a little bit astonished], “irritata” [irritated], “smaniosa” [mad] (p. 199), “[s] ento dell'ira” [in a transport of anger], “con ilarità affettata” [with feigned hilarity] (p. 201), "agitata sforzandosi alla calma” [agitated but forcing herself to remain calm], "collerica” [choleric], "riscaldata" [warmed up], "rabbiosa" [furious] (p. 202). Gozzi goes on burlesquing and ridiculing his heroine in this scene, which is one of the most delightful in Moreto's comedy: in the garden where Diana tried to seduce her ostensibly disdainful suitor by singing to him, Teodora is presented as sitting "in una positura di cochettismo" [in a flirtatious posture] (p. 228) with "un'abito da giardiniera, pittoresco, bizzarro, e modestamente lascivo" [a picturesque peasant dress, bizarre and modestly lecherous] (p. 226).

Another important difference between Teodora and Diana consists in the explanations provided by the two playwrights as to why their heroines find the idea of marriage so intolerable. In Moreto's version, it is Diana's extensive study of ancient mythology and philosophy that has led her to a false understanding of love as responsible for all the world's troubles, ${ }^{18}$ and to her resultant challenging of the social order. ${ }^{19}$ Moreto, however, does not condemn the learned woman as such, but rather his heroine's misinterpretation of the function of knowledge, and intellectual activity disconnected from real life. Indeed, Polilla's use of antiquated and Macaronic Latin indicates the death of the classical learning which Diana cherishes. ${ }^{20}$

Gozzi modernises the sources from which Teodora's convictions are derived: it is not just her reading of ancient fiction, but especially her encounter with modern French Enlightenment philosophy that has made the princess an "illuminata",

18 Moreto, El desdén, con el desdén, vv. 440-450, vv. 824-827, vv. 828-884.

19 Frank P. Casa, "Diana's Challenge in El desdén con el desdén," Romanistisches Jahrbuch 23 (2010), pp. 307-318, pp. $317 \mathrm{f}$.

20 Janet B. Norden, “Moreto's Polilla and the Spirit of Carnival,” Hispania 68.2 (1985), pp. 236241, p. 239. 
the enlightened one ("GIANNETTO: La ga la vovana de esser filosofa; la vol renderese particular con dei novi sistemi; la vol superar tutti i talenti del secolo" [GIAN.: She has the will to be a philosopher; she wants to be unique, conversant with new systems, she wants to surpass all the talents of the century] (p. 157); “TEODORA: Secol felice, illuminate menti / Voi l'uom studiaste, e a me la traccia apriste / Della scienza al ver [...]"; [TEoD.: Happy age, enlightened minds, / you studied man and opened for me the way / of true science] (pp. 176-177)). However, the validity of Enlightenment thought is likewise questioned through the character of Giannetto, Gozzi's spokesperson, who also ironically calls himself a philosopher, although insisting on the practical aspect of his wisdom: "GIAN.: Mi no go letture, nè studio, ma spero de esser più filosofo della Principessa Teodora. Studio i caratteri, osservo le cause, e i effetti, che le produse sui anemi, e cavo delle dottissime conseguenze" [GIAN.: I do not read nor do I study, but I hope to be more of a philosopher than the princess Teodora. I study the characters, I observe the causes and the effects that they produce on the human soul, and deduce the most intellectual consequences] (p. 158).

Over the course of the play, Giannetto argues that Donna Teodora's philosophical principles exhibit a dangerous rhetorical emptiness, or at least an inability to connect words with concrete human experiences. The character of Teodora thus incarnates all the Enlightenment ideas that the playwright himself criticised throughout his entire theatrical production: the spirit of tolerance, freedom of discussion and argument, the desire to overcome traditional socio-economical values, and the ungrounded abstraction of the philosophes' system of reasoning. ${ }^{21}$ Donna Teodora's refusal to marry can also be seen in this light, since it undermines the structure of the patriarchal family and dissolves established hierarchies, and can be considered as Gozzi's counter-Enlightenment critique of the philosophes, who cared little about politics, society or any issue of national importance.

Moreover, whereas Moreto allows his protagonists to argue their cases (indeed, Diana and Carlos spend most of their time challenging each other's positions on the questions of love, gratitude and free will), ${ }^{22}$ Gozzi's Donna Teodora is repeatedly attacked and ridiculed by the other characters, who blame her enlightened

21 On the anti-philosophe discourse in Europe, see Darrin M. McMahon, Enemies of the Enlightenment: The French Counter-Enlightenment and the Making of Modernity (Oxford: Oxford University Press, 2001), esp. pp. 189-201.

22 Frank Casa (“Diana's Challenge,” p. 308) has pointed out that a primary element of Moreto's dramatic technique consists in setting off two or more characters to confront each other. Already the title, Desdén con el desdén, hints at the existence of two equal forces destined to mutual annihilation in order to allow a positive force of love to emerge. 
education for the princess's views. Her lady-in-waiting exclaims that she is "matta, è matta, è matta" [mad, mad and mad] (p. 178), suggesting that Enlightenment philosophy is itself tantamount to madness. Teodora's father, Don Riccardo, allows her to do as she pleases, but he too sees her rejection of marriage as a manifestation of insanity ("RIC.: Avrai delle ragion fondate, e forti / Per difendere in te quell'avversione, / Che follia sembra in ver”; [RIc.: You have your reasons, valid and strong, / To defend your aversion (towards marriage), / which in reality seems to be a madness] (p. 174)), while Giannetto calls the princess a "fanatica" [fanatic] (p. 159).

This radical departure from the Spanish source makes one suspect that Gozzi may have had very personal reasons for this denigration and mockery of Enlightenment principles, for which Teodora serves as a mouthpiece. The antagonistic and militant character of Gozzi's literary production came from a lifelong habit of contesting and countering other authors' work and lent itself well to his self-posturing. Indeed, his Fiabe teatrali originated from debates on the reform of the comic theatre and provided Gozzi with a potent weapon to wage war against his rival playwrights, Carlo Goldoni (1707-1793) and Pietro Chiari (1712-1785), whom he saw as guilty of transforming everyday life into material for the stage. When $L a$ Principessa filosofa was performed in 1772, both of Gozzi's enemies had already left Venice. However, according to the playwright, the political and cultural life of the city was no less under threat from numerous "impostors" who were invading the Venetian stage with translations from French bourgeois drama. ${ }^{23}$ One of them, who also happened to be a woman, was especially responsible for spreading dangerous Enlightenment ideas in Italy through her productions of French didactic drama. Gozzi’s new enemy was Elisabetta Caminer Turra (1751-1796), and it is certainly no coincidence that La Principessa filosofa was originally staged precisely at the moment when the first volume of Caminer's Composizioni teatrali moderne (1772-1774), a compilation of her adaptations from French theatre, appeared in a printed edition.

To summarise the points I have made thus far: the main differences between Gozzi's play and its source consist first of all in the significant alteration of Moreto's ideological message, which is particularly evident in the portrayal of the female protagonist. While Moreto's play is centred on the right and wrong ways of understanding philosophy and applying it to everyday life, Gozzi's teatro spagnolesco provided the playwright with a space where he could self-consciously reflect on contemporary trends in the literary field and counteract the "pernicious" influence of Enlightenment ideas.

23 On the anti-French function of Gozzi's adaptations from Golden Age Spanish theatre and their counter-Enlightenment message, see Gozzi, La più lunga lettera di risposta, pp. 9, 34, 45, 54. 
Secondly, the difference between the Spanish source text and its Italian adaptation stems from the construction of the dramatis personae. As I pointed out, the transformation of the gracioso into the figure of "Veneziano faceto" [funny Venetian fellow $]^{24}$ Giannetto clearly shows the adaptation of the Spanish play to the tastes of Venetian audiences. Moreover, whereas Moreto's delightful comedy is distinguished by the psychological finesse with which the lovers' relationships are portrayed, Gozzi tends to extreme psychological simplification of his protagonists. His disdainful princess of Barcelona and her suitor represent another variant of the Chinese princess Turandot and her lover Calaf, whereas Giannetto is, if not exactly the commedia dell'arte mask of Pantalone, then a modernised version of him. The simplification of characters is also evident in the secondary figures of Cesare's rivals, who appear ridiculous since they come to Barcelona not in search of love, nor to conquer the princess, but because of a frivolous desire to court women (p. 154). Overall, the simplification of the characters' psychology combined with the story of disturbed social order and the final re-establishment of balance made of Gozzi's adaptation a reproduction of his theatrical fables in another guise.

This raises another important question, namely how to explain the immediate and tremendous success that Gozzi's comedy enjoyed, ${ }^{25}$ considering, on the one hand, its extremely polemical character and the easily recognisable targets of his satire, and, on the other hand, the fact that the playwright resorted to the Spanish material precisely out of the necessity to refurbish his repertoire based on the marvellous, whose novelty had worn off and whose popularity had declined.

\section{Author's Pen, Actor's Voice}

One possible explanation for the play's success is that Gozzi was working not only with the source text, but he was also tailoring the dramatis personae to the abilities of his acting troupe. For example, the homonymy of the play's protagonist and the actress who played her, Teodora Ricci (1750-ca. 1806), suggest that the playwright is sincere when he claims in his memoirs that he studied and probed the minds of his performers while constructing every single role in his "poetic caprices":

24 Gozzi, Preface to La Principessa filosofa, p. 148.

25 Ibid., p. 147: "Egli ha cagionato un'irruzion favorevole del Pubblico, e si volle replicato a furore diciotto sere" [(The play) caused an auspicious stir among the audience, and was repeated with immense success eighteen times]. 
[...] studiai, e penetrai filosoficamente tanto bene gli spiriti, e i caratteri de' miei soldati, che tutte le parti da me scritte ne' miei capriccj poetici teatrali, composte con la mira all'anima dei miei personaggi e a quelli addossate, erano esposte sul Teatro per modo che sembrava che uscissero da' loro proprj cuori naturalmente, e per ciò piacevano doppiamente. ${ }^{26}$

[I studied and grasped philosophically the spirits and the characters of my soldiers so well that I composed all the parts in my poetic theatrical caprices with the aim of fitting them to the souls of my actors. Indeed, once presented in the theatre, these parts seemed to come so naturally from their hearts that they were doubly pleasing to the public.]

Indeed, if we compare the behaviour of Donna Teodora with the description of Ricci that Gozzi provides in his memoirs, the female protagonist seems to mirror the neurasthenic and impetuous temperament of the actress who, in her later years, suffered from a disease of the nerves and died in a mental hospital:

Impetuosa e fervida di temperamento, e ambiziosa per se medesima come un Lucifero, ella fremeva, piangeva, entrava nel letto colla febbre leonina, bestemmiava il momento in cui aveva accettato di entrare nella Compagnia del Sacchi, e di venire a Venezia. [...] Fu allora che, avendo conosciuto il di lei carattere, composi il mio Dramma della Principessa Filosofa per formarle una parte che stesse bene al suo dosso. ${ }^{27}$

[Of fervid and impetuous disposition, and as ambitious as a Lucifer, she trembled, cried and went to bed with a leonine fever, cursing the moment she had agreed to enter the Sacchi company and come to Venice. It was then that, having come to understand her character, I wrote my play, The Princess Philosopher, in order to compose for her the role that would suit her well.]

It is thus highly probable that the success of the play and of the performer-who after the first performance immediately attained the status of la "stella più splendente tra le Comiche" [the most resplendent star among comic actresses], "una Attrice inarrivabile nella bravura" ${ }^{28}$ [an actress unsurpassable in her skills]-was due largely to the fortunate consonance between the character and the actress, who hurled herself into the emotionally charged passages, with which she identified.

It is also no coincidence that Gozzi, the fierce defender of improvised comedy, chose not to make use of the commedia dell'arte stock characters ("[v]olli da questo Dramma lontane le nostre maschere"), nor that Giannetto is the only figure who somehow resembles the type of Pantalone. The playwright decided to modernise this mask character, turning him into the figure of "Veneziano faceto," because of the actor, Giambattista Rotti, a relatively recent arrival in Sacchi's company. Rotti joined the troupe in 1769, on his return from Vienna, where he had been employed as a copyist of Metastasio and had performed the Goldonian repertoire. Thus,

26 Gozzi, Memorie inutili, part 2, chap. 1, vol. 2, p. 420; my italics.

27 Ibid., part 2, chap. 9, vol. 2, p. 462.

28 Ibid., part 2, chap. 10, vol. 2, p. 466. 
Gozzi's decision to eliminate the masks was also guided by the necessity to adapt the role to the actor, who brought an abundance of Goldonian characterisation to his performances in the troupe. It is also worth mentioning that, after his return to Italy, Rotti translated Beaumarchais's Les deux amis, ou Le négociant de Lyon.

Such tailoring of the dramatis personae to the performers' individual skills and previous experiences is also evident in the parts of Donna Teodora's suitors, Don Gastone and Don Alfonso, which were entrusted to the actors Luigi Benedetti and Francesco Bartoli. Both specialised in the role of the "second lover," but they were both also translators and dramatists. Indeed, Benetti distinguished himself with his excellent performance in the role of Milord Bonfil in Goldoni's Pamela and with his co-translation into Italian (with Antonio Sacchi) of the Spanish comedy, Offender colla finezza by Girolamo Viglayzan. ${ }^{29}$ Francesco Bartoli, Teodora Ricci's husband, composed five comedies and tragi-comedies, which were regularly staged by the Sacchi troupe, and in 1773, at the request of the capocomico, he adapted Il Finto Muto, ovvero il Mezzano de' proprj affronti ${ }^{30}$ from the Spanish original. Bartoli also authored Le Notizie istoriche de' comici italiani (1782), the work that for the first time placed actors rather than playwrights at the centre of attention, and seeks to acknowledge their "diritto di essere considerati persone di spirito per il magistero della loro arte, e di avere qualche luogo fra i letterati, come autori di commedie e tragedie" [their right to be considered people of intellect for the mastery of their art and to have a place among the men of letters as the authors of comedies and tragedies]. ${ }^{31}$ Bartoli offers a sincere and reliable description of the environment of the comic actors, and also provides the following portrait of Sacchi, the director of Gozzi’s troupe:

Non è il Sacco solamente un Comico materiale, ma è d'un ingegno non spoglio di cognizioni, specialmente intorno alla Storia Universale, mostrandosi nelle conversazioni di dotte persone illuminato, ed erudito; oltre di ciò egli possiede la lingua Francese, e la Spagnola, e nelle occasioni di dover mettere in Scena qualche nuova rappresentazione, o Comica, o Tragica che sia, sa molto bene istruire i suoi Comici, insegnando ad essi il vero modo di eseguire con puntualità, ed accuratezza. ${ }^{32}$

29 Biblioteca Nazionale Marciana di Venezia, Fondo Gozzi, 9.10, c. 9r; see also Giulietta Bazoli, "La vita spettacolare dei testi," in: Gutiérrez Carou, ed., Metamorfosi drammaturgiche, pp. 129-145, p. 136. 30 Bazoli, Lorditura e la truppa: Le Fiabe di Carlo Gozzi tra scrittoio e palcoscenico (Padova: Il Poligrafo, 2012), p. 255.

31 Quoted in Rosalba Milan, Francesco Bartoli: Arte e Teatro nell'Italia del Settecento (Rovigo: Minelliana, 1990), p. 57.

32 Francesco Bartoli, Notizie istoriche de' Comici italiani intorno all'anno MDC fino a' giorni presenti: Opera ricercata, raccolta, ed estesa da Francesco Bartoli bolognese accademico d'onore clementino, 2 vols. (Padova: Conzatti, 1782), vol. 2, p. 148. 


\begin{abstract}
[Not only is Sacchi a comedian but he also has a mind not entirely stripped of knowledge, especially on the topic of Universal History, and in conversations with learned people, he shows himself to be well-educated and erudite. Moreover, he masters the French language and the Spanish, and on occasions when he has to stage a new performance, whether comic or tragic, he knows very well how to instruct his comic actors, teaching them the true way of punctual and accurate execution.]
\end{abstract}

Bartoli's description thus shows how far removed the capocomico was from the cliché of the ignorant director of the comic troupe, solely motivated by financial considerations. Indeed, it was Sacchi who, aware of the necessity to meet the demands of an insatiable theatrical market, brought the works of Golden-Age Spanish drama to Gozzi's attention, as the playwright himself points out in his memoirs: "[i]l Sacchi mi mandava tratto tratto de' fasci di quelle strane, e mostruose opere di quel Teatro; la maggior parte erano da me scartate, e rifiutate” [Sacchi sent me one bundle after another of those strange and monstrous works of that Spanish theatre; I rejected or discarded most of them]..$^{33}$ In claiming for himself the merit of accepting or refusing the scripts, the playwright is skirting the fact that the idea of revamping the company's repertoire through the Spanish adaptations was as much Sacchi's as his own. Indeed, Bartoli's accounts, as well as the profiles of the actors engaged in the production of La Principessa filosofa, show that their role in the choice of repertoire and in the success of the productions was much more decisive than Gozzi was willing to acknowledge. These profiles also testify to the emergence of the new figures of the comic actor and the capocomico, who were well-educated and highly professional, attentive to the smallest details of what would appear on stage.

\title{
“Comica Famigliola": Actors-Translators-Creators
}

The mid-eighteenth-century theatre industry was thus a collective product of joint authorship by playwrights and actors, infinitely adaptable to both the tastes of the public and the abilities of theatre troupes. In fact, for Bartoli, Italian theatre practice was characterised by this intense collaboration between dramatists and actors, which ultimately generated the audience's interest in theatrical performances. In his correspondence with Giuseppe Baretti, Gozzi himself explains (and complains) that "[s]e nel cartello d'invito esposto da questa Truppa, non si leggono i nomi loro [...], sono perduti tosto due terzi de' concorrenti al loro

33 Gozzi, Memorie inutili, part 2, chap. 20, vol. 2, p. 542. 
Teatro" 34 [if one does not see their names on the playbill (...), two thirds of theatre-goers are irretrievably lost].

Yet, on the many pages of his memoirs and theoretical works dealing with the genesis and poetics of his theatre, ${ }^{35}$ Gozzi robs his actors of any description of their artistic profiles and even removes their names. ${ }^{36}$ Apart from his portrayal of Teodora Ricci (who was not only Bartoli's wife, but also happened to be the playwright's lover), Gozzi remains silent regarding the specific contribution of his players to Italian and European theatrical culture. Especially symptomatic in this respect is Gozzi's silence concerning Rotti (who brought Goldonian characterisation to Sacchi's company) and the purely caricatural portrait of Bartoli:

[...] buona persona, e che prima di fare il Comico, aveva fatto il Librajo. Quell'arte aveva lasciato in lui una spezie di fanatismo letterario. Leggeva tutto il giorno, e tutta la notte, e scriveva de' grossi volumi da porre alle stampe, co' quali, diceva egli, d'essere certo di fare un grosso guadagno, e delle investite per sè ed eredi. La sua indefessa, faticosissima sterile applicazione, lo alienava dalle cure domestiche, delle quali lasciava il peso, e la direzione alla Moglie, niente chiedendo per sé, e niente badando alle sue scarpe rotte, e alle sue calzette infangate, forse per imitare un filosofo. ${ }^{37}$

[(...) a good man, who before becoming a comic actor, was a book agent. That art left in him a species of literary fanaticism. He read all day and night and wrote big volumes to be submitted to publishers with which-he used to say-he was certain of making a huge profit, and investments for himself and his heirs. His tireless, exhausting and sterile work alienated him from household chores, the burden of which he left to his wife, asking nothing for himself and caring nothing about his broken shoes and his muddy socks, perhaps in order to imitate a philosopher.]

However, not only does Gozzi not acknowledge the merit of his actors as translators, dramatists and practically as his co-authors, but the few mentions of them in his writings are also accompanied by disparaging descriptions of the comic troupe with which the playwright collaborated for more than twenty years:

Cotesta truppa [...] è composta quasi interamente di stretti parenti a tale, ch'ella si può chiamar più una comica famiglioula, che una comica Truppa. La morigeratezza ne' costumi di questa brigatella, la gratitudine, ch'ella sa dimostrare, come si deve credere, a' doni utili,

34 Gozzi, Lettere, ed. Fabio Soldini, I giorni (Venezia: Marsilio, 2004), p. 114.

35 See in particular the Manifesto to the Colombani edition (1772), Il Ragionamento ingenuo $e$ storia sincera dell'origine delle mie dieci Fiabe teatrali (1772), and La più lunga lettera di risposta (1804), the last detailed authorial analysis of Gozzi's theatrical works.

36 In order to find specific information on Francesco Rotti or the innamorati Luigi Benedetti and Petronio Zanarini, we have to look at Bartoli's extensive annotations or Goldoni's Mémoires. 37 Gozzi, Memorie inutili, part 2, chap. 12, vol. 2, p. 478. 
che le vengono fatti, il merito nell'arte sua, le preghiere di soccorsi, la persecuzione, [...] non mi lasciarono fermare il pensiero in tutto di abbandonarla. ${ }^{38}$

[This troupe (...) consists almost entirely of close relatives, so that it would be more precise to call it a comic family than a comic troupe. However, the moderation in the costumes of this brigatella, the gratitude that it duly demonstrates for the useful gifts bestowed on it, the merit in its artistic skills, the insistent prayers for help, the persecution (...) did not allow me to consider abandoning it altogether.]

Tutto il resto della Compagnia, nel tempo ch'io presi a soccorrerla, ed a prendere prattica con quella, era di vecchi, di vecchie, di figure infelici abili, di personaggi agghiacciati, di ragazzi, e ragazze inesperti. ${ }^{39}$

[All the rest of the company, during that time when I began to help and hang around them, consisted of old men and women, unhappy figures, appalling characters and inexperienced boys and girls.]

Even more astonishing is that Gozzi's general silence concerning his players and his dismissive descriptions of their inadequate abilities in his memoirs and prefaces are to be found side by side with references to the "friendly assistance" that the playwright generously grants them free of charge. ${ }^{40}$ But while Gozzi wants to make it seem as if Sacchi's troupe was languishing in a crisis of ideas after its return from Portugal, in reality it was a company of the first rank in the panorama of European theatre, endowed not just with excellent performers but also with its own creative playwrights.

\section{Self-Promotion, Authorial Agency and the Cultural Net}

What conclusions can be drawn from the analysis of the events surrounding the adaptation of Moreto's Desdén con el desdén for the Italian stage and the staging of Gozzi's Principessa filosofa? First of all, it is apparent that in no other domain is the question of authorial agency as central as it is in the theatre, and nowhere

38 Gozzi, Preface to Zeim, re dei Genj, in: Opere edite ed inedite, vol. 4, pp. 5-17, pp. 6 f.

39 Gozzi, Memorie inutili, part 2, chap. 1, vol. 2, p. 417.

40 See Gozzi's Appendice al Ragionamento ingenuo, in: Gozzi, Il ragionamento ingenuo, ed. Alberto Beniscelli, Testi della cultura italiana (Genova: Nolan \& Costa, 1983), p. 95: "Il nuovo genere, con cui, dopo il genere fiabesco, immaginai di soccorrere con utilità nel teatro l'italiana truppa comica del Sacchi, lo volli trarre dagli argomenti del teatro spagnolo" [The new genrewhich, following the fairy-tale genre, I imagined would be of some utility in the theatre of Sacchi's Italian comic troupe-I wanted to draw from the themes of the Spanish theatre]. 
is it more problematic. Gozzi's silence on his actors' contribution to the creative process leads one to think that it might be worth revisiting Michel Foucault's influential essay "What is an Author?" but to do so in order to consider the alternative question of "where is the author?" and to ask how the conceptualisation of intellectual property for dramatic literature developed differently to the way it did for non-dramatic forms. Whereas the first of these questions is of a more rhetorical nature, I will attempt to answer the second one in my concluding remarks.

The example of Gozzi's teatro spagnolesco illustrates two parallel processes that took place in mid-eighteenth-century Venice. On the one hand we witness the professionalisation of actors, and on the other hand the growing preoccupation of playwrights with crafting their own distinctive authorial identity. Gozzi's self-fashioning and self-promotion in the prefaces to his plays and his memoirs serve as a solid illustration of these processes, precisely because, despite his own repeatedly expressed a lack of interest in having his dramatic works printed or in receiving any personal acknowledgement or financial compensation, ${ }^{41}$ his paratextual silence on the performing troupe's contribution to the creative process makes it clear that Gozzi was in fact preoccupied with legitimising his dramatic production and with reinforcing his position on the literary Parnassus.

But, if the early modern theatre as a site of textual production was largely incompatible with various strategies of individualisation, and the absence of clearly defined notions of dramatic authorship constituted the norm rather than the exception, ${ }^{42}$ what was it that nevertheless led to the emergence of the concepts of intellectual property and authorship in eighteenth-century dramatic

41 For a far-reaching discussion of the rhetorical strategies that Gozzi repeatedly deploys to feign his resistance to having his theatrical works printed and the playwright's paratextual statements about the transposition of plays from the stage to printed form in the Colombani edition, see Anna Scannapieco, Carlo Gozzi: la scena del libro (Venezia: Marsilio, 2006).

42 According to Stephen Orgel, "What is a Text?," Research Opportunities in Renaissance Drama 24 (1981), pp. 3-6, "that the authority of a text derives from the author [...] is almost never true" (p. 3) in the case of Renaissance dramatic texts: "A play was a collaborative process, with the author by no means at the centre of the collaboration. The company commissioned the play, usually stipulated the subject, often provided the plot, often parcelled it out, scene by scene, to several playwrights. The text thus produced was a working model, which the company then revised as seemed appropriate. The author had little or no say in these revisions: the text belonged to the company, and the authority represented by the text-I am talking about the performing text-is that of the company, the owners, not that of the playwright, the author." (ibid.) See also Anny Guimont, "La comedia en colaboración: recursos escénicos y teatralidad en Caer para levantar," Bulletin of the Comediantes 49 (1997), pp. 319-336, on collaborative writing in Spanish Golden Age theatre, with specific reference to Moreto's comedies. 
literature-which, at least as far as Italy is concerned, can be considered a liminal case for early modern drama?

My answer to this question is that in this period we witness a significant change in the perception and the role of theatre, in that it began to be recognised as a privileged site for social debate and a powerful means of reform. of course, theatrical performances have always been imbued with transgressive or subversive potential. However, Gozzi's extremely polemical self-posturing, the deployment of his theatrical fables and the Spanish adaptations to counteract the influence of the Enlightenment (and to wage war against those who were disseminating it in the Italian theatre of the day-Carlo Goldoni, Pietro Chiari, Elisabetta Caminer) testifies less to the personal characteristics of the playwright than to the fact that theatre had become a social and cultural tool capable not only of commenting on, but of influencing and changing reality.

To use Gozzi's own words (which are not dissimilar from Diderot's statements on the matter), theatre took the place of the pulpit, becoming "un pergamo [...] più efficace a rovesciare le teste, che non è un pergamo della Chiesa per raddrizzarle" [a Pergamon that is more efficient in turning heads than a pulpit of the church is in straightening them]. ${ }^{43}$

Moreover, Gozzi's case also seems to illustrate several points that have to be addressed in order to develop the notion of culture as a dynamic net into a working concept, namely: what is the role of authorial agency in the circulation of forms and artefacts? How does authorial agency, or what Foucault famously termed "the author's function," determine the circulation and the subsequent performances of dramatic texts? Gozzi's reduction of collaborative activity to his sole authorship can be seen as the manifestation of the playwright's determination to control the circulation of his theatrical production. As Foucault states, "[t]he author's name [...] indicates the status of th[e] discourse within a society and a culture" ${ }^{44}$ and it is simultaneously used as an anchor for interpreting a text. In other words, the author performs the function of a controlling mechanism, since a discourse that comes equipped with an author's name is not immediately consumed and forgotten. ${ }^{45}$ Indeed, if we consider the "Gozzi myth" and the "Gozzi vogue" created by the German Romantics, the Venetian playwright was undoubtedly successful in establishing an enduring artistic reputation. Foucault, however, goes on to claim that authorial agency has a restraining function in "the free circulation, the free manipulation, the free composition, decomposition, and recomposition

43 Gozzi, La più lunga lettera di risposta, p. 50.

44 Michel Foucault, "What Is an Author?" trans. Josué V. Harari, in: The Foucault Reader, ed. Paul Rabinow (New York, NY: Panteon Books, 1984), pp. 101-120, p. 107.

45 Ibid., p. 114. 
of fiction. ${ }^{{ }^{46}}$ But does this assertion remain valid with regard to texts that are performed? Theatre is a live art and notoriously ephemeral, and the German and Austrian reception of Gozzi's tales and of his Spanish plays, ranging from high-quality productions by gifted directors (such as Friedrich Wilhelm Gotter or Friedrich Ludwig Schröder) to the abrupt decline not in quantity or variety of forms but in the quality of productions, ${ }^{47}$ clearly testifies to the fact that the determination of concepts of authorial intellectual property in the mid-eighteenth century did not exercise any controlling influence on the dramatic texts that were modified or even deformed in their subsequent circulation and performance.

Although it is hardly possible to establish the impact and the exact extent of the playwright's agency by examining the production of a single playwright or even a single national culture, the events surrounding the staging of La Principessa filosofa and the history of the performances over the centuries of Gozzi's theatrical works in general seem to demonstrate that Foucault's claim concerning the restraining function of the author in the free circulation of artworks within the cultural net does not hold true for theatrical works.

46 Ibid., p. 119.

47 Gozzi's plays have been adapted as melodramas, musical plays, operas and operettas. See Hedwig Hoffmann Rusack, Gozzi in Germany: A Survey of the Rise and Decline of the Gozzi Vogue in Germany and Austria, with Especial Reference to the German Romanticists (1930; repr. New York, NY: AMS Press, 1966), pp. 56 ff. 